\title{
A REVIEW OF PHYTOCHEMICAL AND PHARMACOLOGICAL STUDIES OF Piper retrofractum Vahl.
}

\author{
Ni Komang Sri Lumbung Artha Wardani ${ }^{1}$, Ni Putu Eka Leliqia ${ }^{1 *}$ \\ ${ }^{1}$ Department of Pharmacy, Faculty of Mathematics and Natural Sciences, Udayana University \\ Corresponding author email: eka_leliqia@unud.ac.id
}

\begin{abstract}
Background: Javanese long pepper (Piper retrofractum Vahl.) is a plant that commonly found in Southeast Asia and is empirically used to treat various diseases. It is known that the phytochemical content in plants is one factor responsible for its pharmacology activities. The study of the pharmacological effects of herbal ingredients both pre-clinically and clinically is an attempt to prove their empirical properties. Aims: This review article aims to provide information to academics and the public regarding phytochemical studies and pharmacological activity that have been carried out regarding the Javanese long pepper plant. Methods: Article preparation was carried out through literature studies from various national scientific journals, international journals, and online reference books. Javanese long pepper data search system was based on chemical content and pharmacological activity studies either in vitro, in vivo, or clinical trials. Results: Phytochemical studies have shown that the plant parts of Javanese long pepper contain compounds such as alkaloids, saponins, tannins, flavonoids, steroids, triterpenoid, and glycosides. Based on studies of its pharmacological activity, Javanese long pepper has been reported to have antimicrobial, antioxidant, cytotoxic, analgesic, androgenic, aphrodisiac, antihyperlipidemic, antihyperuricemic, lowering leukocyte count, antileishmanial and immunostimulant effects. Conclusion: The efficacy of Javanese long pepper has been scientifically proven to have pharmacological effects either through in vitro or clinical studies which can be taken into consideration for the development of traditional medicinal products.
\end{abstract}

Keywords: Javanese Long Pepper, Piper retrofractum, Phytochemical, Pharmacology activity

\section{INTRODUCTION}

Currently, people tend to change their lifestyle towards a "back to nature". Globally, people are starting to use traditional herbal medicines to maintain their health. There are 40,000 types of medicinal plants that have been known in the world, and 30,000 of them are found in Indonesia. Based on this, $90 \%$ of medicinal plants are found in the Asian region ${ }^{[1]}$. The Javanese long pepper plant (Piper retrofractum Vahl.) is one of the herbal ingredients that can be developed into traditional medicinal products in Indonesia.

Javanese long pepper has long been known as a plant that is widely used as traditional medicine. This plant is native to Southeast Asia and is known as hihatsumodoki in Japan. These plants are widely cultivated in Indonesia and Thailand $^{[2]}$. Javanese long pepper in Indonesia are found in Java, Sumatra, Bali, Nusa Tenggara, and Kalimantan, where the main production center of this plant is on Madura $^{[3]}$.

The Javanese long pepper plant is closely related to the pepper plant and is included in Piperaceae family ${ }^{[4]}$. The taxonomy of Javanese long pepper, namely kingdom plantae; magnoliphyta division; magnoliopside class; piperales order; 
piperaceae family; piper genus; and the species Piper retrofractum ${ }^{[5]}$. Based on its morphology, Javanese long pepper is a climbing plant. The leaves are round, lanceolate, and wide; green to dark green. The fruit has varying shapes and sizes ranging from small lengths (cylindrical), flat length (filiform), elliptical (conical), and short round (globular). The stem is round and large; has a diameter of $\pm 5-7 \mathrm{~cm}$; length of the main stem $2.93-9.82 \mathrm{~cm}$; The color of the stem varies greatly from black, brown to blackish brown ${ }^{[6]}$.

Traditionally, the Javanese long pepper plant is used for the treatment of digestive function disorders, asthma, hypertension, influenza, and for treating flatulence ${ }^{[7]}$. Based on its empirical properties, many studies have been carried out related to the pharmacological effects of Piper retrofractum plants. Several studies revealed that the phytochemical contained in this plant has pharmacological activities, including antimicrobial ${ }^{[8]}$, antioxidant ${ }^{[9]}$, cytotoxic $^{[10]}$, analgesic ${ }^{[11]}$, androgenic ${ }^{[12]}$, aphrodisiac $^{[13]}$, antihyperlipidemic ${ }^{[14]}$, antihiperuricemia ${ }^{[15]}$, reducing the number of leukocytes ${ }^{[16]}$, antileishmanial ${ }^{[17]}$, and immunostimulants $^{[18]}$.

The increasing number of scientific studies regarding the phytochemical content and pharmacological activities of Javanese long pepper is expected to provide information to the public about the potential of this plant as a traditional medicine. In addition, this article can be used by researchers as a consideration in developing Javanese chili research for the treatment of diseases.

\section{METHODS}

The method used in this review article was a literature study. Literature was collected from original articles published in national and international scientific journals online through searches on the Scopus portal and Google Scholar. Literature can also be in the form of a reference book. The main keyword used is the name of the plant
Piper retrofractum, then it is further selected to obtain data related to its phytochemical content and pharmacological activity.

\section{RESULTS AND DISCUSSIONS}

Javanese long pepper (Piper retrofractum Vahl.) are known to have pharmacological activities. The type of chemical content of this plant plays an important role in determining its pharmacological effect. Phytochemical screening and isolation of chemical compounds from Javanese long pepper is one way to obtain information about the chemical content and isolate compounds. The pharmacological effect of an herbal ingredient can be determined through preclinical tests which include in vitro and in vivo testing, as well as through clinical trials. In vitro testing is carried out to determine the efficacy of these herbal ingredients so that they can predict and determine the mechanism of the compound to work with target receptors. This test is carried out outside the body of a living thing such as in bacterial cultures, isolated cells, or isolated organs. In vivo testing is carried out to see the behavior of the test animals so that they can provide information about their biological system after being given the test material ${ }^{[19]}$. According to BPOM RI (2015), clinical trials are studies using humans as subjects to find or confirm clinical, pharmacological and/or other pharmacodynamic effects, and/or identifying any unwanted reactions, and/or studying absorption, distribution, metabolism and excretion to ensure the safety and/or effectiveness of the product studied $^{[20]}$.

\section{Chemical Content}

The fruit, leaves, stems, and roots of Javanese long pepper contain alkaloids, saponins, tannins, flavonoids, steroids, triterpenoid, and glycosides ${ }^{[21]}$. The results of phytochemical screening conducted by Krisnawan et al. (2017), showed that the 
aqueous extract of Javanese long pepper leaves positively contained flavonoids and saponins $^{[22]}$. Yuliatmoko and Febria (2018) also reported that dried leaves of Javanese long pepper contain terpenoid compounds ${ }^{[23]}$. Research by Insanu et al., (2017) revealed that Javanese long pepper leaf extract contains flavonoids, tannin, quinone, and steroid/triterpenoid compounds $^{[24]}$.

Several studies had been succeeded in isolating the chemical compounds from Javanese long pepper. This plant is known to contain piperine, chavicin, palmatic acid, tetrahydropiperic acid, 1-undecylenyl-3, 4methylledioxy benzene, piperidine, essential oils, N-isobutyldeka-trans-4dienamid, and sesamin ${ }^{[4]}$. Jamal et al., (2013) reported that there are 4 main components of the essential oil of Javanese long pepper leaves, namely germacrene $D$ (24.20\%), tetramethylcyclo [5.3.1.0 (4.11)] undec-8-ene (17.73\%), Ar-turmerone $(11.55 \%)$ and benzyl benzoate (6.28\%). Meanwhile, 3 other sesquiterpene, namely $\alpha$-cubebene (3.55\%), $\beta$-cubebene (2.59\%), and $\beta$-cadinene $(2.49 \%)$ as well as sesquiterpene alcohol curlone $(2.67 \%)$ and derivatives of phenyl propanoate, 2methoxy-4- (2-propenyl) -phenol (2.05\%) showed a content between $2-4 \%{ }^{[8]}$.

Amad et al., (2016) also stated that other compounds have been isolated from Javanese long pepper fruit, namely piperine, methyl piperate, sylvatin, and piperlonguminine ${ }^{[25]}$. According to the findings reported by Bodiwala et al. (2007), there are 3 compounds produced by $n$ hexane and methanol extracts from the stem of Javanese long pepper. The results of the isolation showed that the n-hexane extract of Javanese long pepper stems contained sesamin (lignans) and pellitorine (amide) compounds. Meanwhile, methanol extract contains piplartine (amide) compounds ${ }^{[17]}$.

\section{Antimicrobial Activity}

The leaves of Javanese long pepper are known to have antibacterial activity as shown by a study conducted by Jamal $e t a l$., (2013). The activity test was carried out in vitro with the diffusion method to see the inhibitory diameter and the dilution method to determine the value of the minimum inhibitory concentration (MIC) of the test sample against bacteria. The results showed that essential oils with a concentration of $50 \%$ proved to have antibacterial activity against Bacillus subtilis (NBRC 3134), Micrococcus luteus (NBRC 14218), Staphylococcus aureus (NBRC 14276) with an inhibitory diameter of $8.5 ; 8.0$; and 9.7 $\mathrm{mm}$; but it had no effect on Eschericia coli (NBRC 14237). It is also known that the essential oil from the leaves of Javanese long pepper has a MIC value of $2 \%(\mathrm{v} / \mathrm{v})$ against $B$. subtilis. Tetramethylcyclo [5.3.1.0 (4.11)] undec-8-ene, germacrene $D, A r$-turmerone, and benzyl benzoate were known as main components of essential oils contained in Javanese long pepper leaves in this study. Cell leakage testing and observation by Scanning Electron Microscopy (SEM) were carried out on $B$. subtilis. Exposure of B. subtilis bacterial cells with essential oil of Javanese long pepper leaves at a concentration of $2 \%$ and $4 \%$ caused cell leakage of cellular metabolites such as proteins and nucleic acids, as well as ions from metals $\left(\mathrm{K}^{+}\right.$and $\left.\mathrm{Ca}^{2+}\right)$. SEM observations showed that there were morphological changes in these bacterial cells ${ }^{[8]}$. Gauthier (2006) explains that the leak is thought to affect changes in bacterial morphology that can inhibit cell wall synthesis. Ion leakage is caused by damage to cell membranes and increased membrane permeability. Damage to the cell membrane will make it easier for organic acids to penetrate the cytoplasmic membrane and cause changes in membrane stability which eventually leads to ion leakage ${ }^{[26]}$.

Panphut et al., (2020) reported that Javanese long pepper fruit which were extracted with several solvents such as acetonitrile, methanol n-hexane, isopropanol, and dichloromethane had 
antimicrobial activity with a range of inhibition zone diameters $0.5-8.0 \mathrm{~mm}$. The acetonitrile extract showed antimicrobial activity against $E$. coli, B. subtilis, Enterococcus faecalis, Klebsiella pneumoniae, Pseudomonas aeruginosa, Salmonella typhi, S. aureus, Vibrio parahaemolyticus XN89, Vibrio paraparahaemolyticus 5HP, and Candida albicans with MIC values of 36.0; 71.50; 4,$50 ; 143.50 ; 143.50 ; 9.0 ; 71.50 ; 71.50$; 71.50; and $1.0 \mathrm{mg} / \mathrm{mL}$. Methanolic extract also showed antimicrobial activity against E. coli, B. subtilis, E. faecalis, $K$. pneumoniae, $P$. aeruginosa, S. typhi, S. aureus, $V$. parahaemolyticus XN89, $V$. paraparahaemolyticus 5HP, and $C$. albicans with MIC value of 22.50; 5,50; $45.0 ; 90.0 ; 179.50 ; 11.0 ; 45.0 ; 45.0 ; 22.50$; $0.50 \mathrm{mg} / \mathrm{mL}$. The $\mathrm{n}$-hexane extract only showed activity against $C$. albicans with a MIC value of $2.50 \mathrm{mg} / \mathrm{mL}$. Isopropanol extract showed antimicrobial activity against E. coli, B. subtilis, E. faecalis, S. typhi, S. aureus, $V$. parahaemolyticus $\mathrm{XN89,V}$. paraparahaemolyticus $5 \mathrm{HP}$, and C. albicans with MIC values of 18.0; 9.0; $71.50 ; 9.0 ; 35.50 ; 71.50 ; 18.0 ;$ and 10.0 $\mathrm{mg} / \mathrm{mL}$; and dichloromethane extracts showed antimicrobial activity against $E$. coli, B. subtilis, E. faecalis, S. typhi, S. aureus, $V$. parahaemolyticus XN89, V. paraparahaemolyticus 5HP, and $C$. albicans with MIC values of $80.0 ; 80.0$; $40.0 ; 10.0 ; 80.0 ; 80.0 ; 40.0 ;$ and 18.0 $\mathrm{mg} / \mathrm{mL}$. Based on this study, it is known that the bioactive compound Javanese long pepper which was extracted with methanol had better potential against pathogenic microorganisms $^{[27]}$.

The results of research conducted by Krisnawan et al. (2017), reported that the aqueous extract of Javanese long pepper leaves various concentrations also had antibacterial activity against $S$. aureus. The extract with a concentration of $20 \%, 35 \%$, $50 \%, 65 \%$, and $80 \%$ had an inhibitory diameter of $1.40 \mathrm{~mm} ; 2.38 \mathrm{~mm} ; 2.88 \mathrm{~mm}$; $2.76 \mathrm{~mm} ; 4.49 \mathrm{~mm}$ respectively. Based on these results, aqueous extract with a concentration of $20-65 \%$ were categorized as having weak activity, while aqueous extract with a concentration of $80 \%$ was categorized as having moderate activity ${ }^{[22]}$. Pan et al., (2009) stated that there are three categories of inhibitory power, the weak activity with an inhibition diameter of $0 \mathrm{~mm}$ - 3mm, a moderate activity with an inhibition diameter of $3 \mathrm{~mm}-6 \mathrm{~mm}$ and the third category is strong with an inhibition diameter of $>6 \mathrm{~mm}^{[28]}$.

Amad et al., (2016) revealed that Javanese long pepper fruit had an antituberculosis effect. In vitro testing on the bacterium Mycobacterium tuberculosis strain H37Ra showed that the methanol extract and the isolates contained therein, namely piperlonguminine and piperine, had antibacterial activity. The MIC value of the methanol extract was $25 \mu \mathrm{g} / \mathrm{mL}$, while piperlonguminine and piperine had weaker activity with MIC values of $50.0 \mu \mathrm{g} / \mathrm{mL}$. Two other compounds that have also been isolated from methanol extract, namely sylvatine and methyl piperate, did not have antibacterial activity ${ }^{[25]}$.

\section{Antioxidant Activity}

Based on research conducted by Jadid et al. (2016), Javanese long pepper that was extracted with several solvents had antioxidant activity. The activity was determined using using DPPH method. The $\mathrm{IC}_{50}$ value obtained from the n-hexane extract was $57.66 \mu \mathrm{g} / \mathrm{mL}$; ethyl acetate of $66.12 \mu \mathrm{g} / \mathrm{mL}$; and methanol $101.74 \mu \mathrm{g} / \mathrm{mL}$. In this study, the antioxidant activity was classified into 3 categories. Strong antioxidant activity had a range of $\mathrm{IC}_{50}$ values of $10-50 \mu \mathrm{g} / \mathrm{mL}$; moderate antioxidants have an $\mathrm{IC}_{50}$ value range of 50$100 \mu \mathrm{g} / \mathrm{mL}$, and weak antioxidants have IC values $>100 \mu \mathrm{g} / \mathrm{mL}$. Based on these categories, n-hexane and ethyl acetate extracts were classified as antioxidants with moderate activity, while methanol extracts were classified as weak antioxidants ${ }^{[9]}$. 
Mulia et al., (2016) conducted a study comparing the antioxidant activity of Javanese long pepper fruit extracts from Pamekasan and Karangasem. The results showed that samples from Pamekasan had weaker antioxidant activity ( $\mathrm{IC}_{50} 288.037$ $\mu \mathrm{g} / \mathrm{mL}$ ) than samples from Karangasem ( $\mathrm{IC}_{50} 285.61 \mu \mathrm{g} / \mathrm{mL}$ ). However, based on the $\mathrm{IC}_{50}$ value, the antioxidant activity of both samples is still relatively weak ${ }^{[29]}$.

\section{Cytotoxic Activity}

Javanese long pepper extract has been shown to have a cytotoxic activity against Artemia salina Leach shrimp larvae, MCF7 breast cancer cells, HeLa cell line (continuous cell line derived from cervical cancer epithelial cells), T47D breast cancer cells and lung cancer cells (SCLC-H22 and NCI-H187). According to findings reported by Clarasati et al., (2016), extract and fractions of Javanese long pepper fruit had cytotoxic activity against Artemia salina Leach shrimp larvae. The $\mathrm{LC}_{50}$ value of 95\% ethanol extract, n-hexane fraction, ethyl acetate fraction, and aqueous fraction were $44.05 \mu \mathrm{g} / \mathrm{mL} ; 70.79 \mu \mathrm{g} / \mathrm{mL} ; 79.43$ $\mu \mathrm{g} / \mathrm{mL}$; and $112.2 \mu \mathrm{g} / \mathrm{mL}$ respectively. Extracts and fractions of Javanese long pepper were stated to have cytotoxic activity because they had an $\mathrm{LC}_{50}$ value lower than $1,000 \mu \mathrm{g} / \mathrm{mL}^{[10]}$.

Mulia et al., (2016) reported that Javanese long pepper fruit extract from Karangasem and Pamekasan had cytotoxic activity against MCF-7 breast cancer cells. The treatment of various concentrations of Javanese long pepper extract from the two regions were able to have effect on these cells. There was a decrease in the $\mathrm{IC}_{50}$ value with increasing concentration. Samples from Karangasem and Pamekasan had cytotoxic activity with $\mathrm{IC}_{50}$ values of $63.283 \mu \mathrm{g} / \mathrm{mL}$ and $83.662 \mu \mathrm{g} / \mathrm{mL}$. Based on these data, the cytotoxic activity of both samples is classified as active because the $\mathrm{IC}_{50}$ value is in the $50-100 \mu \mathrm{g} / \mathrm{mL}$ range ${ }^{[29]}$. Hasan et al. (2016) also researched on MCF-7 breast cancer cells that was exposed to $70 \%$ ethanol extract of Javanese long pepper fruit from various regions in Indonesia. The results of the cytotoxic test on MCF-7 breast cancer cells showed that the extracts from Paranggupito 1 (Central Java), Paranggupito 2 (Central Java), Girintontro (Central Java), Air Naningan 1 (Lampung), and Air Naningan 2 (Lampung) had a value IC $_{50}$ successively 80.43; $126.09 ; 181.52 ; 54.35 ; 4.35 \mu \mathrm{g} / \mathrm{mL}$. These results indicate that the Javanese long pepper from Air Naningan 2 have the best cytotoxic activity. Further testing on MCF7 breast cancer cells given the extract from Air Naningan 2 with a concentration of 250 $\mu \mathrm{g} / \mathrm{mL}$ showed that the cancer cells were severely damaged ${ }^{[30]}$.

Based on research conducted by Ekowati et al. (2011), it is known that $96 \%$ ethanol extract of Javanese long pepper fruit had cytotoxic activity against HeLa cells with an $\mathrm{IC}_{50}$ value of $47.409 \mu \mathrm{g} / \mathrm{mL}$ and against T47D with an $\mathrm{IC}_{50}$ value of 92.38 $\mu \mathrm{g} / \mathrm{mL}$. Ekowati et al., (2011) also combined this extract with red ginger rhizome. The results showed increased cytotoxic activity against HeLa and T47D cells when the two ingredients were combined, with smaller $\mathrm{IC}_{50}$ values for the two test cells, namely $33 \mu \mathrm{g} / \mathrm{mL}$ and 53 $\mu \mathrm{g} / \mathrm{mL} \cdot{ }^{[31]}$ Compound that role play in the cytotoxic activity of this plant is piperine (alkaloid group). The piperin can protect cells from cancer by binding to proteins in mitochondria and triggering apoptosis without damaging normal cells, through increased activity of antioxidant enzymes such as superoxide dismutase, catalase, and glutathione peroxidase. In addition, piperine can inhibit NFkB so that it can prevent tumor formation through TNF- $\alpha$ and inhibit the angiogenesis process ${ }^{[32,33]}$.

Amad et al., (2016) reported that the methanol extract of Javanese long pepper fruit and their isolates (piperine and piperlonguminine) had cytotoxic activity against lung cancer cells [SCLC-H22 and NCI-H187 (ATCC CRL-5840)]. The cytotoxic activity can be shown based on 
the percentage value of the growth inhibition of the test cells. The methanol extract of Javanese long pepper with a concentration of $5 \mu \mathrm{g} / \mathrm{mL}$ also had a $\%$ inhibitory value of SCLC-H22 and NCIH187 lung cancer cells of 38.83 and $96.71 \%$, respectively. Piperine with a concentration of $25 \mu \mathrm{g} / \mathrm{mL}$ had a $\%$ inhibitory value against SCLC-H22 and NCI-H187 lung cancer cells of 7.68 and $15.58 \%$, respectively. Meanwhile, piperlonguminine with a concentration of $25 \mu \mathrm{g} / \mathrm{mL}$ had a \% inhibitory value against SCLC-H22 and NCI-H187 lung cancer cells of 11.59 and $15.04 \%$. The $\mathrm{IC}_{50}$ value was only obtained in the methanol extract of $20.98 \mu \mathrm{g} / \mathrm{mL}$ against NCI-H187 $7^{[25]}$.

\section{Analgesic}

Evacuasiany et al., (2010) revealed that the ethanol extract of Javanese long pepper fruit at a dose of $3 \mathrm{~g} / \mathrm{kg} \mathrm{BW}$ given to mice orally had analgesic activity equivalent to acetosal at a dose of $0.42 \mathrm{~g} / \mathrm{kg} \mathrm{BW}$. The ethanol extract at doses of $0.75 \mathrm{~g} / \mathrm{kg} \mathrm{BW}$ and $1.5 \mathrm{~g} / \mathrm{kg}$ BW also showed analgesic activity but this activity was still weaker than acetosal. The analgesic effect is thought to be due to decreased prostaglandin synthesis so that inhibit sensitivity to pain responses ${ }^{[11]}$.

\section{Androgenic}

Based on research conducted by Moeloek et al., (2010), the fruit extract of Javanese long pepper had androgenic activity that has been tested clinically. The $100 \mathrm{mg} /$ day extract given to several male hypogondism patients for 60 days had an androgenic effect. Its effect was indicated by an increase in testosterone levels in $78 \%$ of the total number of patients (9 patients). However, the androgenic effect of the extract was categorized as weak androgenic because it was unable to significantly reduce follicle stimulating hormone and luteinizing hormone levels $(\mathrm{p}<0.05)^{[12]}$.

\section{Aphrodisiac}

Tominik (2018) examined the aphrodisiac effect of the Javanese long pepper fruit extract. The administration of extract at a dose of $210 \mathrm{mg} / \mathrm{kg} \mathrm{BW}$ to albino mice (Mus musculus) for 36 days was able to increase diameter of the seminferus tubule, the weight of the testis, the core Leydig diameter, the thickness of the germinal seminiferous tubular epithelium, Sertoli cells, the Leydig cell count, the spermatogenesis index, and the associate cell significantly $(\mathrm{p}<0.05)$. The increase in spermatogenic cells is thought to be due to an increase in metabolism in the body. This causes an increase in energy for protein synthesis which affects the spermatogenesis process when mitotic division increases ${ }^{[13]}$.

According to findings reported by Rahmawati and Bachri (2012), an infusion that contained combination of Piper retrofractum at a dose of $210 \mathrm{mg} / \mathrm{kg} \mathrm{BW}$, Centella asiatica at a dose of $546 \mathrm{mg} / \mathrm{kg}$ BW, and Curcuma domestica at a dose of $910 \mathrm{mg} / \mathrm{kg}$ BW gave aphrodisiac effect to male rats. This infusion was orally administered for 7 days simultaneously. The effect was indicated by sexual behavior intensity (introduction, coitus and climbing frequency). The male rat that was given an infusion had higher sexual behavior intensity than control group significantly $(\mathrm{p}<0.05)$. This is thought to be due to the piperine content of Javanese long pepper $^{[34]}$. Muslichah (2011) also reported that the piperine content of the Javanese long pepper fruit extract at a dose of 1.6 $\mathrm{mg} / \mathrm{kg} \mathrm{BW}$ and an insoluble fraction of $\mathrm{n}$ hexane free of piperine from javanese long pepper fruit at a dose of $29.10 \mathrm{mg} / \mathrm{kg} \mathrm{BW}$ which given to male rats for 27 days orally had an aphrodisiac effect ${ }^{[35]}$.

\section{Antihyperlipidemia}

Based on research conducted by Mustofa et al. (2014), the ethanol extract of 97\% Javanese long pepper fruit had the potential to be an antihyperlipidemic. This was indicated by the ability of this extract 
to influence the lipid profile and histology of the coronary arteries of male white rats (Rattus norvegicus) which were given a high-fat diet for 49 days orally. In the negative control group, the treatment of a high-fat diet in the test animals showed an increased lipid profile of total cholesterol, Low Density Lipoprotein (LDL) and triglyceride levels and significantly decreased High Density Lipoprotein (HDL) compared to normal controls $(\mathrm{p}<0.05)$. In addition, a high-fat diet also causes the intactness of endothelial cells and can even be found atherosclerotic plaques accompanied by thickening of the aortic wall. Meanwhile, in the treatment group where the test animals were given a high-fat diet along with the extract at a dose of 40 $\mathrm{mg} / \mathrm{kg} \mathrm{BW}$ showed a decrease in total cholesterol, LDL and triglyceride levels as well as a significant increase in HDL levels compared to negative controls $(\mathrm{p}<0.05)$. In the histology of the coronary arteries, it showed that the endothelial cells were intact but not atherosclerotic plaques are formed on the walls of the blood vessels ${ }^{[14]}$.

\section{Antihyperuricemia}

Fitriani et al. (2018), tested the antihyperuricemia activity of herbal combination containing Javanese long pepper fruit, broadleaf plantain (Plantago major), and celery (Apium graveolens). Administration of this combination at a dose of $2 \mathrm{~g} / \mathrm{kg} \mathrm{BW}$ to male white rats for 7 days orally, were able to reduce uric acid levels. Flavonoids were thought to be responsible for this activity ${ }^{[15]}$. In addition, this study also reported that giving these herbs at doses of 2, 3, 4, and $5 \mathrm{~g} / \mathrm{kg} \mathrm{BW}$ had no effect on kidney function and liver function tested on white rats for 14 days $^{[36]}$.

\section{Decreased Number of Leukocytes}

A research by Nurhidayah et al., (2019) revealed that the methanol extract of Javanese long pepper fruit with a concentration of $100 \%$ given topically was effective in reducing the number of leukocytes in Wistar rats with traumatic ulcers. Piperine was thought to be an active compound that plays a role in its activity. Piperine is known to stimulate salivary flow, where an increase in salivary $\mathrm{pH}$ can affect the increase in buffer activity in saliva. In addition, piperine is thought to aid in the healing process of lesions because it has antipyretic, analgesic, antifungal, and antibacterial properties ${ }^{[35]}$.

\section{Antileishmanial}

Bodiwala et al., (2007) reported that some extracts of Javanese long pepper stem had antileishmanial activity which was tested in vitro against Leismania donovani promastigotes. The $\mathrm{IC}_{50}$ values of acetone, ethyl acetate, n-hexane, and methanol extracts were $3.5 ; 45 ; 5 ; 7.5 \mu \mathrm{g} / \mathrm{mL}$. In this study also obtained 3 isolates from the extract of n-hexane and methanol. The results of the isolation showed that the nhexane extract contained sesamin and pellitorin. While the methanol extract contained piplartine. Further testing of the isolates showed that only piplartine was known to be active and gave an $\mathrm{IC}_{50}$ value of $7.5 \mu \mathrm{M}$. Antileishmanial was also carried out in vivo using infected hamsters by observing the amastigotes of Leismania donovani. Piplartine at a dose of $30 \mathrm{mg} / \mathrm{kg}$ $\mathrm{BW}$ given intra-peritoneally for 10 days significantly reduced the spleen parasitic burden and spleen weight $(\mathrm{P}<0.05)^{[16]}$.

\section{Immunostimulants}

According to the findings reported by Roseno et al. (2019), it is known that the ethanol extract of Javanese long pepper fruit at a dose of $280 \mathrm{mg} / \mathrm{kg} \mathrm{BW}$ given to test animals orally for 6 days has immunomodulatory activity as an immunostimulant. In this case, the immunostimulant activity of Piper retrofractum extract had a higher phagocytosis index value compared to the comparison group of phytopharmaca immunostimulants of $1.5 \mathrm{x}$; and able to increase peripheral blood neutrophil levels 
which play an important role in the process of phagocytosis ${ }^{[36]}$.

\section{CONCLUSION}

Based on the results of phytochemical studies, the Javanese long pepper plant (Piper retrofractum Vahl.) contains phytochemical compounds of alkaloids, flavonoids, essential oils, saponins, terpenoids, tannins, quinones, steroids/triterpenoids, lignans and amides. Javanese long pepper has also been shown to have pharmacological effects either through in vitro, in vivo, or clinical studies. Activities that have been tested in vitro were antimicrobial, antioxidant, and cytotoxic; activities that have been tested in vivo are analgesic, aphrodisiac, antihyperlipidemic, anti-hyperuricemia, and decreased leukocyte count; The activity which has been tested in vitro and in vivo was antileishmanial; The activity that has been clinically tested was androgenic. These activities are inseparable from the chemical content in the Javanese long pepper.

\section{CONFLICT OF INTEREST}

In the preparation of this article, there is no conflict or interest. This article is written independently without the involvement of other parties who could improperly influence this article.

\section{ACKNOWLEDGEMENT}

Thank you to all parties, especially from the Pharmacy Study Program of the Faculty of Mathematics and Natural Sciences, Udayana University who have provided a lot of assistance in the process of making this article.

\section{REFERENCES}

1. Salim Z, dan Munadi E. Info Komoditi Tanaman Obat. Jakarta: Badan Pengkajian dan Pengembangan Perdagangan; 2017.

2. Takahashi $\mathrm{M}$, Hirose $\mathrm{N}$, Ohno $\mathrm{S}$, Arakaki M, dan Wada K. Flavor
Characteristics and Antioxidant Capacities of Hihatsumodoki (Piper retrofractum Vahl.) Fresh Fruit at Three Edible Maturity Stages. J Food Sci Technol. 2018; 55(4): 1295-1305.

3. Sudarmaji L, Hayati A, dan Rahayu T. Studi Etnobotani Tanaman Cabe Jamu (Piper retrofractum Vahl.) Di Desa Gapura Timur Kecamatan Gapura Kabupaten Sumenep. e-Jurnal Ilmiah Biosaintropis (Bioscience-Tropic). 2019; 4: 26-32.

4. Haryudin W, dan Rostiana O. Stabilitas Karakter Morfologi 10 Aksesi Cabe Jawa (Piper retrofractum Vahl.) di Kebun Percobaan Cikampek. Bul. Littro. 2011; 22(1): 13-22.

5. Boangmanalu RK, dan Zuhrotun A. Review Artikel: Potensi Khasiat Obat Tanaman Marga Piper: Piper nigrum L., Piper retrofractum Vahl., Piper betle Linn., Piper cubeba L. dan Piper crocatum Ruiz \& Pav. Farmaka. 2018; 16(3): 204-212.

6. Haryudin W, dan Rostiana O. Karateristik Morfologi Tanaman Cabe Jawa (Piper retrofractum Vahl.) di Beberapa Sentra Produksi. Bul. Littro. 2009; 20(1): 1-10.

7. Chaveerach A, Mokkamul P, Sudmoon $\mathrm{R}$, and Tanee T. Ethnobotany of the Genus Piper (Piperaceae) in Thailand. Ethnobotany Research \& Applications. 2006; 4: 223-231.

8. Jamal $\mathrm{Y}$, Irawati $\mathrm{P}$, Fathoni $\mathrm{A}$, and Agusta A. Chemical Constituents and Antibacterial Effect of Essential Oil of Javaneese Pepper Leaves (Piper retrofractum Vahl.). Media Litbangkes. 2013; 23(2): 65-72.

9. Jadid N, Hidayati D, Hartanti SR, Arraniry BA, Rachman RY, and Wikanta W. Antioxidant Activities of Different Solvent Extracts of Piper retrofractum Vahl. using DPPH Assay. Proceeding of International Biology Conference. 2016.

10. Clarasati MB, Fitrianingsih SP, dan Suwendar. Uji Sitotoksik Ekstrak dan 
Fraksi Buah Cabai Jawa (Piper retrofractum Vahl) terhadap Larva Udang Artemia salina Leach dengan Metode Brine Shrimp Lethality Test (BSLT). Prosiding Farmasi. 2016; 2(2): 542-546.

11. Evacuasiany E, Santosa S, dan Irwan M. Efek Analgesik Ekstrak Etanol Piper retrofractum Vahl. Pada Mencit Galur Swiss-Webster. Jurnal Medika Planta. 2010; 1(1): 25-34.

12. Moeloek N, Lestari SW, Yurnadi, dan Wahjoedi B. Uji Klinik Ekstrak Cabe Jawa (Piper Retrofractum Vahl) sebagai Fitofarmaka Androgenik pada Laki-laki Hipogonad. Majalah Kedokteran Indonesia. 2010; 60(6): 255-262.

13. Tominik, VI. Uji Berbagai Dosis Ekstrak Buah Cabe Jawa (Piper retrofractum Vahl.) Terhadap Histologi Testis dan Proses Spermatogenesis Mencit Albino (Mus musculus). Jurnal Stikes Muhammadiyah Palembang. 2018; 6(1): 47-57.

14. Mustofa S, Anindito AA, Pratiwi A, Putri AA, dan Maulana $M$. The Influence of Piper retrofractum Vahl (Java's Chili) Extract Towards Lipid Profile and Histology of Rats Coronary Artery with High-Fat Diet. JUKE. 2014; 4(7): 52-59.

15. Fitriani U, Wijayanti E, Nisa N, dan Zulkarnain Z. Aktivitas Ramuan Cabe Jawa, Daun Sendok, dan Seledri Terhadap Tikus Hiperurisemia. Jurnal Tumbuhan Obat Indonesia. 2018; 11(2): 33-39.

16. Nurhidayah R, Anwar R, dan Mayasari LO. Efektivitas Ekstrak Cabe Jawa (Piper retrofractum Vahl.) Terhadap Penurunan Leukosit Tikus Wistar yang Mengalami Ulkus Traumatikus. Jurnal Kedokteran Gigi. 2019; 13(2): 31-36.

17. Bodiwala HS, Singh G, Singh R, Dey CS, Sharma SS, Bhutani KK, and Singh IP. Antileishmanial Amides and Lignans from Piper cubeba and Piper retrofractum. J. Nat. Med. 2007; 61: 418-421.

18. Roseno M, Sudaryat Y, dan Widyastiwi. Aktivitas Immunomodulator Ekstrak Etanol Kemukus (Piper cubeba), Kiseureuh (Piper aduncum), dan Cabe Jawa (Piper retrofractum) pada Mencit Jantan Galur Balb/C. Jurnal Ilmu Kefarmasian Indonesia. 2019; 17(2): 255-261.

19. Hairunnisa, H. Sulitnya Menemukan Obat Baru di Indonesia. Majalah Farmasetika. 2019; 4(1): 16-21.

20. BPOM RI. Tata Laksana Persetujuan Uji Klinik. Jakarta: Badan Pengawas Obat dan Makanan Republik Indonesia; 2015.

21. Zuchri, A. Habitus dan Pencirian Tanaman Cabe Jamu (Piper retrofractum Vahl.) Spesifik Madura. Agrovigor. 2008; 1(1): 39-44

22. Krisnawan, IPG, Putu Sandhi WPA, dan Duniaji AS. Daya Hambat Ekstrak Daun Cabe Jawa (Piper retrofractum Vahl.) Terhadap Pertumbuhan Staphylococcus aureus. Jurnal ITEPA. 2017; 6(2): 1-10.

23. Yuliatmoko W, dan Febria W. Pembuatan Minuman Fungsional dari Buah Cabe Jawa (Piper retrofractum Vahl.). Seminar Nasional "Inovasi Pangan Lokal Untuk Mendukung Ketahanan Pangan". 2018; ISSN: 2656-6796.

24. Insanu M, Marliani L, dan Dinilah NP. Perbandingan Aktivitas Antioksidan dari Ekstrak Daun Empat Tanaman Marga Piper. Pharmaciana. 2017; 7(2): 305-312.

25. Amad S, Yuenyongsawad S, and Wattanapiromsakul C. Investigation of Antitubercular and Cytotoxic Activities of Fruit Extract and Isolated Compounds from Piper retrofractum Vahl. Walailak Journal Sci \& Tech. 2016; 14(9): 731-739. 
26. Gauthier, E. Minyak Atsiri Jilid I, Penerjemah S, Ketaren. Jakarta: Universitas Indonesia Press; 2006.

27. Panphut W, Budsabun T, and Sangsuriya P. In Vitro Antimicrobial Activity of Piper retrofractum Fruit Extracts against Microbial Pathogens Causing Infections in Human and Animals. International Journal of Microbiology. 2020; 1-6.

28. Pan X, Chen F, Wu T, Tang H, and Zhao Z. The Acid, Bile Tolerance, and Antimicrobial Property of Lactobacillus acidophilus NIT. Food Control. 2009; 20: 598-602.

29. Mulia K, Hasan AEZ, and Suryani. Total Phenolic, Anticancer and Antioxidant Activity of Ethanol Extract of Piper retrofractum Vahl from Pamekasan and Karang Asem. Current Biochemistry. 2016; 3(2): 8090.

30. Hasan AEZ, Suryani, Mulia K, Setiyono A, and Silip JJ. Antiproliferation Activities of Indonesian Java Chili, Piper retrofractum Vahl., Against Breast Cancer Cells (MCF-7). Der Pharmacia Lettre. 2016; 8(18): 141-147.

31. Ekowati H, Septiyaningsih, and Harwoko. An Extract of Zingiber officinale and Piper retrofractum Combination and Its Effect to Cancer Cell Line. Indonesian Journal of Cancer Chemoprevention. 2011; 2(1): 173-181.

32. Pradeep CR, and Kuttan G. Piperine is a Potent Inhibitor of Nuclear Factor-nB (NF-nB), c-Fos, CREB, ATF-2 and Proinflammatory Cytokine Gene Expression in B16F-10 Melanoma Cells. International Immunopharmacology. 2004; 4: 1795 $-1803$.

33. Selvendiran K, Singh JPV, Krishnan KB, and Sakthisekaran D. Cytoprotective Effect of Piperine Against Benzowaxpyrene Induced
Lung Cancer with Reference to Lipid Peroxidation and Antioxidant System in Swiss Albino Mice. Fitoterapia. 2003; 74: 109-115.

34. Rahmawati N, and Bachri MS. The Aphrodisiac Effect and Toxicity of Combination Piper retrofractum L, Centella asiatica, and Curcuma domestica Infusion. Health Science Indones. 2012; 3(1): 19-22.

35. Muslichah, S. Potensi Afrodisiak Kandungan Aktif Buah Cabe Jawa (Piper retrofractum Vahl) Pada Tikus Jantan Galur Wistar. Jurnal Agrotek. 2011; 5(2): 11-20.

36. Fitriani U, Dewi TF, dan Wijayanti. Analisis Fungsi Hati dan Fungsi Ginjal pada Tikus Setelah Pemberian Ramuan Cabe Jawa, Daun Sendok dan Seledri. Pros Sem Nas Masy Biodiv Indon. 2019; 5(2): 263-266. 
